\author{
Андрій Юрійович Ерьоменко \\ https://orcid.org/0000-0002-4349-4288 \\ викладач кафедри музично-інструментального виконавства \\ СумДПУ імені А. С. Макаренка \\ yeremenkoandrey80@gmail.com
}

\title{
БАЯННІ П'ЕСИ НА ФОЛЬКЛОРНІ МОТИВИ АНАТОЛІЯ ГАЙДЕНКА
}

\begin{abstract}
Мета роботи. Розгляд баянних n'єс А. Гайденка, пов’язаних з опорою на фольклорні джерела - українські та інонаціональні, спрямований на виявлення способів відтворення композитором духу та стилю народної музики. Методологія дослідження базується на історичному, структурно-функціональному, жанрово-стильовому та інтонаційно-драматургічному методах, застосованих для вивчення жанрових, стилістичних та композиційних особливостей творів. Наукова новизна полягає у з'ясуванні характерних для Гайденка способів роботи з фольклорним матеріалом та впливу жанрових позначень, зафіксованих у заголовковому комплексі п'єс, на їх образний зміст, стилістику, форму, характер викладення музичного матеріалу. Висновки. Виявлено, що серед апробованих в композиторській практиці підходів до втілення музичного фольклору А. Гайденку близький той, що характеризується асиміляцією окремих фольклорних елементів у власному стилі, хоча це не виключає використання фольклорних цитат. Порівняно справжні фольклорні мелодії та авторські теми, створені «в народному дусі», з метою виявлення їхньої спорідненості у метроритмічній, ладовій, мелодичній площинах. Охарактеризовано способи роботи А. Гайденка з тематизмом, які не залежать від генези останнього: точний та варіантний повтор, а також уведення нового тематичного матеріалу, що виступає важливим фактором розгортання музичної думки в баянних n'єсах композитора. Проаналізовано вплив на образний зміст та стилістику творів жанрових позначень, зафіксованих у заголовковому комплексі: коло, хоро, вербунк, коломийка, фантазія, етюд, обробка. Наголошено, що властива розглянутим творам А. Гайденка віртуозність викладення, разом із модельованою імпровізаційністю виконання, є підставою поширити на них позначення «фантазія», адресоване п'єсі для двох баянів «Коло».
\end{abstract}

Ключові слова: творчість А. Гайденка, українська баянна музика, способи перетворення фольклорних джерел в академічній музиці, балканська тематика. 
Yeremenko Andrei, the teacher of the musical and instrumental performance department of Sumy State A. S. Makarenko Pedagogical University

Bayan pieces for folklore motifs by Anatoly Haidenko

The purpose of the work. The bayan pieces by A. Haidenko, connected with the reliance on folklore sources - Ukrainian and foreign, is aimed at revealing the ways of composer's reproduction of the spirit and style of folk music. The research methodology is based on historical, structural-functional, genre-style and intonational-dramaturgic methods used to study genre, stylistic and compositional features of works. Scientific novelty consists in the discovery of A. Haidenko's ways to work with folklore material and the influence of genre designations fixed in the headline complex of pieces, on their figurative content, style, form, and nature of the presentation of the musical material. Conclusions. It is revealed that among the approaches methods to the embodiment of musical folklore that are in composer practice approved, A. Haidenko is chooses the method of assimilation of individual folklore elements in their own style, although this does not exclude the use of folklore citations. Comparison of authentic folklore melodies and author's themes «in the national spirit» becomes the basis for the conclusion about their metrorhythmic, ladylike, melodic relationship. A. Haidenko's methods of working with thematology are outlined, independent of the genesis of the latter: precise and variant repetition, as well as the introduction of new thematic material, which is an important factor in the development of musical thought in the composer's bayan pieces. The influence on the figurative content and stylistics of the works of genre designations fixed in the header complex is analyzed: kolo, horo, verbunk, kolomyka, fantasy, etude, processing. It is noted that virtuosity of the presentation, inherent in the reviewed works by A. Haidenko, together with the simulated improvisation of performance, makes it possible to extend to them the designation «fantasy», addressed to the play for two accordion «Kolo».

Keywords: creativity by A. Haidenko, Ukrainian bayan music, ways of transformation of folklore sources in academic music, Balkan themes.

Еременко Андрей Юрьевич, преподаватель кафедры музыкально-инструментального исполнительства СумГПУ имени А. С. Макаренко

\section{Баянные пьесы на фольклорные мотивы Анатолия Гайденко}

Цель работы. Рассмотрение баянных пьес А. Гайденко, связанных c опорой на фольклорные источники - украинские и инонациональные, направлено на выявление способов воспроизведения композитором духа и стиля народной музыки. Методология исследования базируется на историческом, структурно-функциональном, жсанрово-стилевом и интонационно-драматургическом методах, применяемых для изучения жанровых, стилистических и композиционных особенностей произведений. Научная новизна заключается в обнаружении характерных для А. Гайденко способов работы с фольклорным материалом и влияния жанровых обозначений, зафиксированных в заголовочном комплексе пьес, 
на их образное содержание, стилистику, форму, характер изложения музыкального материала. Выводы. Выявлено, что среди апробированных в композиторской практике подходов к воплощению музыкального фольклора А. Гайденко ближе метод ассимиляции отдельных фольклорных элементов в собственном стиле, хотя это не исключает использования фольклорных цитат. Сравнение подлинных фольклорных мелодий и авторских тем «в народном духе» становится основанием для заключения об их метроритмическом, ладовом, мелодичном родстве. Охарактеризованы способы работы А. Гайденко с тематизмом, не зависящие от генезиса последнего: точный и вариантный повтор, а также введение нового тематического материала, выступающее важным фактором развертывания музыкальной мысли в баянных пьесах композитора. Проанализировано влияние на образное содержание и стилистику произведений жанровых обозначений, зафиксированных в заголовочном комплексе: коло, хоро, вербунк, коломыйка, фантазия, этюд, обработка. Отмечено, что присущая рассмотренным произведениям А. Гайденко виртуозность изложения, вместе с моделируемой импровизационностью исполнения, позволяет распространить на них обозначение «фантазия,, адресованное пьесе для двух баянов «Коло».

Ключевые слова: творчество А. Гайденко, украинская баянная музы$\kappa a$, способы преобразования фольклорных источников в академической музыке, балканская тематика.

Актуальність теми дослідження. Значну частину баянного доробку Анатолія Гайденка складають концертні п'єси, пов'язані з опорою на фольклорні джерела - переважно інонаціональні. В них втілені враження композитора від подорожей просторами колишнього Радянського Союзу та європейських країн - Румунії, Болгарії, Югославії, Чехословаччини, Польщі, Німеччини. Ці поїздки ставали для Анатолія Павловича невичерпним джерелом духовного розвитку та творчого натхнення. Ось що він пригадує у розмові з А. Семешком: «Буваючи за кордоном, намагаюся вивчити хоч мінімум слів та виразів народів тієї чи іншої країни, вслухатися в їх народну музику, що дало мені можливість проникнути, скажемо, у балканський фольклор, написати твори з використанням його стильових рис - інтонацій, ритму, мелізматики, гармонії і особливостей акордеонно-баянної техніки» $[8,65]$. Разом з тим творче звернення А. Гайденка до музики народів світу обумовлене не тільки зовнішніми чинниками - знайомством з чужою культурою в процесі подорожей, але й внутрішніми - щирим інтересом до людського життя, розумінням єдності народів і культур, прагненням до національної автентичності. Вміння А. Гайденка з однаковим успіхом відтворювати властиві музиці різних 
країн особливості дає привід Д. Кужелєву говорити про поліетнічну ментальність митця [6, 61].

Серед концертних п'єс на фольклорні мотиви, створених А. Гайденком, переважають балканські за «походженням». Окрім «Балканського триптиху», назва якого говорить сама за себе, вказівки на країни Балканського півострова $є$ у підзаголовках таких творів як «Коло» («фантазія на південнослов'янські теми») та «Здравейте, другарі!» («болгарське хоро»). «Плетениця» для дуету баянів також має балканське джерело, адже слово, винесене у заголовок, перекладається з сербсько-хорватської мови як «дівоча коса». «Невестіно коло» містить справжню народну мелодію, записану югославським акордеоністом Любічем Павковічем [3]. Назва ще однієї баянної п’єси співпадає з позначенням жанру хороводу у різних балканських народів «Весняна хора». Однак є серед фантазій А. Гайденка і ті, що засновані на враженнях композитора від фольклору інших народів: «Вербунк», «Палехські замальовки», «Коломийка», «Вечір у горах». 3 назв перших трьох творів зрозуміло, що вони написані на основі угорських («Вербунк»), російських («Палехські замальовки») та українських («Коломийка») мотивів, що ж стосується п’єси «Вечір у горах», то тут йдеться про Кавказькі гори і, відповідно, в ній знайшло відображення захоплення А. Гайденка музикою народів Закавказзя.

Аналіз досліджень і публікацій. В музикознавчій літературі баянні п’єси на фольклорні мотиви А. Гайденка висвітлені нерівномірно. Майже усі дослідники, що звертаються до постаті цього композитора, відзначають особливе місце таких творів у його доробку, однак у більшості випадків справа обмежується простим переліком відповідних заголовків. Певним виключенням $є$ навчальний посібник Д. Кужелєва [6], в якому міститься лаконічна характеристика п'єси «Вечір у горах» та «Балканського триптиху» в аспекті переломлення в їх стилістиці ознак «чужого» фольклору. Цікаві спостереження щодо фольклорних джерел «Плетениці» та «Невестіного кола» знаходимо також у посібнику Т. Большакової [3]. Однак питома вага п’єс на фольклорні мотиви в творчому багажу А. Гайденка та їх виконавська затребуваність актуалізує необхідність цілісного аналітичного розгляду цієї групи творів.

Мета дослідження - виявити, яким чином відтворює А. Гайденко дух та стиль чужого фольклору в своїх баянних п’єсах.

Виклад основного матеріалу. У музикознавстві давно проаналізовані та науково обгрунтовані існуючі в композиторській практиці підходи до втілення музичного фольклору. Одним з перших класифікацію 
методів перетворення народнопісенного тематизму обгрунтував угорський композитор та фольклорист Бела Барток. У своїй статті «Про вплив селянської музики на музику нашого часу» він охарактеризував три таких методи: (1) більш-менш точне проведення народної мелодії та гармонізація ії засобами, що не суперечать інтонаційно-ладовим основам першоджерела; (2) осучаснення фольклорного наспіву через застосування новаторських гармонічних та темброво-фактурних прийомів, що покликані врівноважити первісну архаїчність звучання; (3) нецитатне використання фольклорних елементів - інтонаційних, ритмічних, ладових, фактурних - та їх асиміляція у власному стилі композитора [2, 245-249].

Три методи фольклоризму, сформульовані А. Іваницьким, відображають форми існування фольклору в композиторському тексті. Це - (1) обробка народних мелодій, (2) використання фольклорних наспівів в якості тематичного матеріалу для побудови форм академічного типу, (3) сутнісна трансформація фольклорних джерел без цитування. Як бачимо, третій метод в класифікації А. Іваницького співпадає з бартоківським, а перший і другий розрізняються не за ступенем переосмислення першоджерела, а за функцією народного наспіву в композиторському тексті [4].

На формах взаємодії композиторського та фольклорного зосереджує увагу також О. Протопопова, яка пропонує диференціювати: (1) пряме цитування фольклорного матеріалу без його наступного розвитку; (2) обробку народних тем в умовах певного жанру - варіацій, фантазії, сюїти; (3) концептуальне звернення до фольклорної стилізації у конкретному музичному творі; (4) фольклорну стилізацію як визначальний стильовий напрям композитора. Дві останні форми розрізняються рівнем функціонування фольклорної стилізації, під якою дослідниця розуміє поєднання сучасних засобів художнього висловлювання з фольклорними [7, 149].

Спираючись на наведені класифікації, спробуємо розглянути баянні п’єси на фольклорні мотиви А. Гайденка, враховуючи такі моменти. По-перше, цитує композитор справжні народні мелодії чи обмежується асиміляцією характерних фольклорних елементів. Подруге, як працює композитор з фольклорним джерелом, наскільки радикально переосмислює його за допомогою сучасних техніко-композиційних засобів. По-третє, чи впливає жанрове позначення, зафіксоване композитором у заголовковому комплексі, на образний зміст, стилістику, форму, характер викладення музичного матеріалу. 
Почнемо зі з'ясування того, яким є співвідношення у баянних п’єсах А. Гайденка справжніх фольклорних мелодій та авторських тем, створених у народному дусі. Т. Большакова, пишучи про особливу зацікавленість композитора культурою балканських народів, підкреслює той факт, що для нього не характерне звернення до конкретних національних джерел: «Його сприйняття фольклору цього регіону це погляд українського митця на музичне побутування «Балканщини», подібно позиції М. А. Римського-Корсакова та О. П. Бородіна, які у своїй творчості відображали не конкретні музичні культури певних народів, а певний узагальнений образ Сходу» $[3,20]$. Однак це не виключає використання А. Гайденком фольклорних цитат. Так, зі слів самого Анатолія Павловича відомо, що такі цитати є у «Балканському триптиху», «Невестіному колі», концертній фантазії «Коло». Порівняємо декілька музичних тем з «балканських» творів Гайденка.

Тема 3 «Невестіного кола» $є$ справжньою народною темою, записаною югославським акордеоністом Любічем Павковічем та роз-

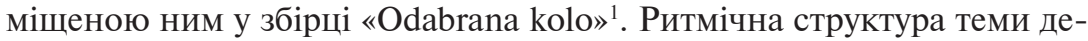
термінована іiі метричною основою. Такт у розмірі 11/8 складається 3 чотирьох різних за тривалістю груп: $2+2+3+2+2$. Однак ці групи об’єднуються у більші утворення завдяки подвійним форшлагам, що прикрашають мелодію, одночасно акцентуючи певну долю такту. В результаті виникає відчуття розподілу такту на дві нерівні частини: $4(2+2)$ і $7(3+2+2)$. Така структура має місце у перших трьох тактах кожного чотиритактного речення, в останньому ж такті ритмічний рух ніби «спотикається»: форшлаги з'являються частіше (на другій, п'ятій та восьмій долях), призводячи до роздроблення такту. В подальшому розгортанні теми (ц. 1) зберігається як принцип внутрішнього членування такту за допомогою форшлагів, так і епізодичне зміщення таких акцентів на його різні долі. Відразу слід сказати, що при гармонізації теми А. Гайденко ускладнив її метроритмічну будову, оскільки фактурна формула «бас-акорд» привнесла додатковий «наголос» у розподіл сильних та слабких долей: бас припадає кожного разу на першу, п’яту та восьму долі, вибудовуючи ще один рівень багатоярусної метроритмічної конструкції теми. Серед ладових особливостей теми необхідно виокремити елементи подвійно-гармонічного мажору, який стає основою для обігрування специфічних ходів на збільшену секунду, а також змінність високих та низьких ступенів

\footnotetext{
${ }^{1}$ Судячи 3 назви збірки, запозичена тема $є$ хорватською за походженням, адже «Odabrana kolo» перекладається як «Вибрані коло» саме з хорватської мови.
} 
ладу. Що стосується мелодичної лінії, то вона складається з низки двозвучних та тризвучних мотивів, які чіпляються один за одного, в цілому ж iї обриси мають заокруглений характер, відповідний до «кругового» характеру танцю («коло»).

У «Весняній хорі» А. Гайденко, за його власними словами, намагався відтворити стилістичні особливості румунської музики, однак цитат не використовував. Оскільки «Весняна хора» написана у формі рондо з двома епізодами, то тут є три самостійні теми - досить контрастні відносно одна одної.

Тема рефрену (т. 10) нагадує запальні румунські танці. Невпинний рух шістнадцяток спирається на басо-акордовий акомпанемент, що ніби підхльостує цей стрімкий звуковий потік, однак несподівані акценти на різних долях такту, створені завдяки епізодичному застосуванню мелізматичних прикрас - трелей, мордентів, форшлагів, порушують рівномірність руху, надаючи йому примхливості та непередбачуваності. Ладовою основою теми є подвійно-гармонічний мінор, що спричиняє постійне використання збільшеної секунди у мелодиці.

Тема першого епізоду несе в собі риси імпровізаційності. Чисельні повторення тонічної сексти ре-сі зрідка відтіняються спадним мотивом від I до V ступеня ( $c i-л я-c o л ь-\phi a-\partial i \epsilon з)$ та висхідною питальною інтонацією ( $c i-л я-\partial о-д і є з)$. Гранична «економність» мелодичних засобів виразності компенсується різноманітністю артикуляційних та мелізматичних прийомів колористичного забарвлення звучання. Національної характерності темі надає також прийом глісандування, який застосовується тут для продовження тривалості звучання основного тону ладу.

Тема другого епізоду поєднує танцювальну основу з емоційною чуттєвістю (ремарка espressivo). Метрична нерегулярність та асиметричність ритмічних фігур тимчасово поступаються місцем рівномірній пульсації та повторюваності мелодико-ритмічних формул. Розмір 6/8 з майже вальсовою фігурою у супроводу та пластичні мотиви, нанизування яких утворює мелодичну лінію, вказують на «жіночі» риси цього танцю. Вишуканості образу надають мерехтіння високих та низьких ступенів, сковзання хроматизмів, витончені глісандо.

Тож, порівняння справжньої фольклорної мелодії з авторськими темами, створеними «в народному дусі», демонструє їх спорідненість, що виявляється в метроритмічній, ладовій, мелодичній площинах. 
Це свідчить про глибоке занурення А. Гайденка в музику балканських народів, ретельну аналітичну роботу з фольклорним матеріалом та досконалість передачі його своєрідності в оригінальному тематизмі.

Способи роботи А. Гайденка із музичним матеріалом фактично не залежать від його генези. Композитор однаково працює з темами, що мають фольклорне походження, і з оригінальними темами, що представляють собою фольклорні стилізації.

Найпростішим способом роботи з музичним матеріалом та, водночас, природним для фольклору є точний повтор тематичних побудов, позначений за допомогою спеціальних абревіатур. Такі повтори доволі часто зустрічаються в різних частинах баянних п’єс А. Гайденка, охоплюючи як невеличкі фрагменти нотного тексту (4-8 тактів), так і доволі розгорнуті. Особливо показовими є невиписані репризи усієї форми, наявні у «Невестіному колі», «Здравейте, другарі», «Вербунку», «Вечорі у горах», фінальній частині «Плетениці».

Однак найчастіше розвиток тематичного матеріалу відбувається у фольклорних п’єсах А. Гайденка шляхом варіювання. У випадках, коли фольклорна мелодія (або авторська тема в народному дусі) зберігає свій первісний вигляд, може змінюватися регістр, тональність, фактура супроводу. До мелодичної лінії також може додаватися новий контрапункт, а якщо йдеться про баянні дуети, то дуже характерним $є$ перерозподіл музичного матеріалу між двома інструментальними партіями. Часткове оновлення звучання досягається зміною ладового нахилу теми, іії ритмічним збільшенням чи зменшенням. Варіювання самої мелодичної лінії, як правило, здійснюється через застосування мелізматичних прикрас. Ще один рівень варіювання - структурний: тема може стискуватися або, навпаки, розширюватися завдяки внутрішнім повторам, секвенціюванню, включенню нових елементів. Одним зі способів оновлення теми є зміна послідовності елементів усередині теми.

Уведення нового тематичного матеріалу, що також виступає важливим фактором розгортання музичної думки та побудови форми [1], для баянних п'єс на фольклорні мотиви А. Гайденка є не менш показовим, ніж варіювання. Зіставлення тем, що вже прозвучали, з новими тематичними утвореннями не тільки переключає музичне розгортання в іншу площину, але й дає можливість переосмислити усе, що відбувалося у тематичній сфері твору раніше.

Використання в межах конкретного твору лише одного способу розвитку зустрічається досить рідко, на практиці різні способи поєд- 
нуються, однак можна говорити про домінування якогось одного 3 них. Так, наприклад, «Невестіно коло» будується на варіюванні однієї теми. Форму цієї п'єси можна відобразити у схемі А а $\mathrm{A}_{1} \mathrm{a}_{1} \mathrm{~A}_{2} \mathrm{a}_{2}$ $\mathrm{A}_{3} \mathrm{a}_{3} \mathrm{~A}_{4} \mathrm{a}_{4(\text { предик })} \mathrm{A} \mathrm{a}$, де $\mathrm{A}, \mathrm{A}_{1}, \mathrm{~A}_{2}, \mathrm{~A}_{3}$ та $\mathrm{A}_{4}$ - варіанти теми, $a, a_{1}, a_{2}$, $a_{3}$, та $a_{4}$ - варіаційні повторення варіантів. Варіанти теми - досить самостійні за інтонаційним змістом та рівні за значущістю, їх послідовність демонструє наявність рис, які об'єднують і які відрізняють їх від попередніх. Варіаційні ж повторення кожного з варіантів містять незначні видозміни, пов'язані, перш за все, з оновленням фактури та перерозподілом матеріалу між партіями двох баянів.

Твір для двох баянів «Коло» містить цілу низку тем - фольклорних або наближених до них, які змінюють одна одну ніби у калейдоскопі. Їх послідовність зафіксовано у схемі А В C D E G F J, де літерами позначено самостійні тематичні утворення, що наповнюють відповідні розділи форми. Усередині розділів кожна тема отримує варіантно-варіаційний розвиток. В чергуванні тематичних розділів присутній контраст танцювального та пісенного начал, хоча танцювальність, безумовно, переважає. Більше того, варіювання пісенних тем у середині розділів спрямоване в бік активізації руху, перетворення розспівності на танцювальність або моторику. Тож, концертну фантазію «Коло» можна охарактеризувати як танцювальну сюїту, де на композиційному рівні домінує принцип зіставлення більш-менш контрастного тематичного матеріалу, а становлення форми відбувається шляхом уведення нових тем, які корелюють одна з одною через взаємодію різних жанрових начал.

Баянні п'єси на фольклорні мотиви А. Гайденка можна систематизувати за жанровим показником. Майже усі вони мають вказівки на жанр або у підзаголовку, або безпосередньо у заголовку. Так, назва балканського танцю-хороводу «хоро» або «коло» фігурує у заголовках трьох творів («Весняна хора», «Невестіно коло», «Коло») та у підзаголовках ще двох (болгарське хоро «Здравейте, другарі!» та панорама коло балканських слов'ян «Плетениця»). Назва «Вербунк» апелює до однойменного угорського танцю. Твори для двох баянів «Коло» та «Коломийка», заголовки яких вже містять згадку про той чи інший жанр, мають додаткові позначення: «концертна фантазія на південно-слов'янські теми» в «Коло» та «обробка» в «Коломийці». «Балканський триптих» Гайденко позначив у підзаголовку як «Три концертних етюди», а «Вечір у горах» та «Палехські замальовки» як «концертні п’єси». 
Коло - народний танець-хоровод - широко розповсюджений в країнах Балканського півострова ${ }^{1}$. Хореографічна сторона танцю пов'язана переважно з рухами по колу. Як правило, танцюристи тримаються за руки або обіймають один одного за плечі. Від майстерності та винахідливості виконавців залежить і тривалість цього танцю, який може складатися з необмеженої кількості самостійних за типом руху епізодів, що утворюють сюїту. Музична сторона хоро/коло доволі різноманітна. Темп коливається від повільного до швидкого, метрична основа може бути дводольною $(2 / 4,4 / 4)$, тридольною $(3 / 4$, 9/16) або асиметричною (5/16, 7/16, 11/16).

Як хореографічні, так і музичні особливості хоро/коло різняться у тих чи інших регіонах Балканського півострова. Іноді танець навіть називається за місцем побутування, наприклад, «орхейське», «македонське», «родопське» хоро/коло, в інших випадках отримує назву від особи чи події, на честь яких виконується. Так, серед творів А. Гайденка $€$ «Невестіно коло», пов'язане, напевно, з весільним святом, та «Весняна хора», виконання якої приурочене, вочевидь, до приходу довгоочікуваного тепла після зимових морозів. Що ж стосується регіональних різновидів, то двічі композитор дає узагальнену вказівку на балканських («Плетениця») або південних слов’ян («Коло»), а у п’єсі «Здравейте, другарі!» уточнює географічну адресу, називаючи хоро «болгарським».

Можливо, що саме болгарські орієнтири обумовили особливу складність метроритмічної організації твору під назвою «Здравейте, другарі!», адже відомо, наскільки своєрідними є притаманні болгарському фольклору метри та комбінації ритмічних фігур. У болгарському хоро А. Гайденка складність метроритмічної сторони музики тягне за собою необхідність використання у нотному записі таких розмірів як 7/16, 10/16, 11/16, 15/16 при дуже частих їх змінах. В побудові музичних мотивів, фраз, речень спостерігаються різноманітні сполучення симетричних та несиметричних структур. Синкопи чергуються з подвійними пунктирами, а додатковим фактором ускладнення метроритмічної будови твору виступає рясна мелізматика, що прикрашає мелодію та акцентує щоразу інші долі такту. «Круговий» характер танцю обумовлює часом і звуковисотні обриси фактурних ліній: переважання обертального типу інтонацій, постійні повернення до одного тону, хвилеподібність мелодичного руху.

\footnotetext{
${ }^{1}$ Коло - це назва, під якою цей танець існує в Сербії та Хорватії. В Болгарії його називають «хоро», в Румунії та Молдові - «хора».
} 
На танцювальний жанр вказує і назва такого твору Анатолія Гайденка як «Вербунк». Вербунк ${ }^{1}$ походить від давніх стрибучих танців пастухів, які звалися «угросами» і нерідко виконувалися із оголеними мечами, з посохами чи батогами. Притаманні вербувальним танцям музичні риси пізніше стали сприйматися як уособлення стильових особливостей національної музики, а слово «вербункош» наприкінці XVIII - початку XIX століть вказувало вже не стільки на танцювальний жанр, скільки на стиль угорської інструментальної музики в цілому. У «Вербунку» А. Гайденка знайшли відображення практично усі ознаки стилю вербункош: чотиридольний метр, пунктирні ритми (переважно обертального типу), збільшені секунди, що репрезентують подвійно-гармонічний мінор, численні форшлаги та морденти, які прикрашають мелодію та, як правило, акцентують сильні долі такту або посилюють агогічне розширення наприкінці фраз. В формі п’єси відобразилося також характерне для вербунку та похідного від нього чардашу зіставлення повільного та швидкого розділів.

П'єса «Коло» має підзаголовок «концертна фантазія на південнослов'янські теми». Жанр фантазії традиційно пов'язується зі свободою висловлювання, втіленням імпровізаційного начала, спрямованістю на пошуки нового. Структурні особливості фантазії випливають з властивої семантичному ядру жанру ідеї свободи, вільного вираження думок і почуттів. Звідси - типова для фантазійних форм багатоепізодність, де епізоди чергуються за принципом контрастного зіставлення темпу, фактури, динаміки, метроритмічних показників. Характерним для музичних фантазій є також широке використання віртуозних фігураційно-пасажних форм викладу, їх поєднання з варіаційними елементами. В фантазії А. Гайденка «Коло» можна спостерігати майже усі вказані риси жанру. Її форма складається з восьми епізодів, заснованих на яскравих, в більшості випадків контрастних темах. Нанизування все нових тем та їх варіантів створює враження вільного імпровізування, коли кожна група виконавців по черзі демонструє свої вміння, намагаючись «перетанцювати» один одного.

Ще один балканський опус А. Гайденка - «Балканський триптих» - має підзаголовок «Три концертних етюди». «Етюдність» цих п’єс виявляється через віртуозні прийоми гри та остинатність викладення. I якщо віртуозність властива практично всім іншим розгля-

\footnotetext{
${ }^{1}$ Назва танцю походить від німецького слова «Werbung», що перекладається як «вербувати», «рекрутувати», тому що з середини XVIII століття набір солдат в австроугорську армію супроводжувався саме такими танцями.
} 
нутим у статті творам, то витриманість однієї фактурної формули та технічного прийому - особливість тільки п’єс «Балканського триптиху», що обумовлено приналежністю їх до жанру етюду.

Дешо відокремлена від більшості творів А. Гайденка на фольклорні мотиви його «Коломийка». Це єдиний серед баянних опусів композитора зразок власне обробки. Мелодія, покладена в основу цього твору, є дуже відомою, вона часто поєднується з різними текстами або виконується як суто інструментальна композиція. «Коломийка» Гайденка належить до типу етнографічно-адаптаційної обробки [5], про що свідчать пряме цитування народної мелодії, збереження їй образно-емоційного змісту, відтворення властивого їй гармонічного плану, куплетно-строфічна форма. Зберігаючи характерні для жанру коломийки особливості побудови, А. Гайденко, разом з тим, збагачує викладення введенням та наскрізним розвитком додаткових тематичних елементів - спадного мелодичного контрапункту та синкопованої фактурно-ритмічної формули. Сполучення ж типового для фольклорних жанрів принципу варіантної куплетності з системою тональних, фактурних і ритмічних арок надає формі п’єси цілісності та довершеності.

Два твори А. Гайденка не мають спеціального жанрового позначення: «Вечір у горах» та «Палехські замальовки». Композитор (а слідом за ним і дослідники) називає їх просто «концертними п'єсами». Відмінні риси цих творів детерміновані фольклорним джерелом, до якого звертається автор.

Образний та жанровий контраст двох розділів п’єси «Вечір у горах», нагадуючи аналогічні зіставлення повільного та швидкого руху в таких п’єсах А. Гайденка як «Вербунк», «Плетениця», «Коло», демонструє зовсім інший національний вектор пошуків композитора, зі всією очевидністю виявлений у «східному» стилістичному забарвленні твору. Повільна частина має вокальну природу, підкреслену темповим позначенням Andante cantabile і відчутну в характері мелодичного малюнку. Стрімкий рух тріолей, підтриманих на сильних долях такту різкими акордами, в швидкій частині п'єси передає стійкі уявлення про войовничі кавказькі танці, в яких чоловіки намагаються показати властиву їм силу та спритність.

Відсутність жанрового підзаголовку у «Палехських замальовках» частково компенсується словом «замальовки» у його назві. Апелюючи до таких жанрових позначень як «картина», «ескіз», «фреска», «ілюстрація», що доволі часто зустрічаються в композиторській прак- 
тиці, А. Гайденко намагається викликати у слухачів живописні асоціації. Останні виникають завдяки постійній грі барвами - регістровими, ладотональними, динамічними, тембровими. Особливо цікавими $€$ політональні нашарування мелодичних ліній чи акордових пластів.

Помітною рисою усіх розглянутих в статті творів А. Гайденка є віртуозність викладення. В «балканських» опусах підгрунтям ефектної віртуозності звучання $€$, безумовно, властива народному акордеонному виконавству орнаментальність, про що свідчить насиченість музичної тканини цих п’єс усілякими мелізматичними прикрасами - мордентами, форшлагами, групетто, трелями, які буквально «нанизуються» одне на одне. Однак у віртуозного стилю як «балканських» опусів А. Гайденка, так і тих, що спираються на угорський, російський, грузинський чи український фольклор, $є$ й інші джерела жанрові. На нашу думку, позначення «фантазія», адресоване п’єсі для двох баянів «Коло», може бути поширене практично на всі твори композитора, розглянуті вище. Залучення різноманітних прийомів віртуозної гри, винахідливі способи оновлення тематичного матеріалу, значне місце фігураційно-пасажних форм викладення - все це, разом із модельованою імпровізаційністю виконання, покликане втілити культ артистичного «Я», що складає найважливіший компонент семантичного ядра фантазії як музичного жанру.

Наукова новизна статті полягає у з'ясуванні характерних для А. Гайденка підходів до втілення музичного фольклору різних країн та впливу жанрових позначень, зафіксованих у заголовковому комплексі п’єс, на їх образний зміст, стилістику, форму, характер викладення музичного матеріалу.

Висновки. Таким чином, у відтворенні культури різних народів А. Гайденко використовує як справжні народні мелодії, так і авторські, що узагальнюють специфічні ладові та мелодико-ритмічні риси певного національного різновиду фольклору. Провести чітку межу між фольклорним та авторським не завжди уявляється можливим через те, що композитор органічно поєднує фольклорні елементи з власним мовним арсеналом. Що ж стосується сучасних техніко-композиційних засобів, то, на відміну від інших своїх творів, у розглянутих баянних п'єсах А. Гайденко не «зловживає» ними, намагаючись зберегти необхідний баланс традиційного та новаторського. Саме це стає підставою для висновку, який робить Д. Кужелєв у книзі «Баянна творчість українських композиторів» стосовно місця Анатолія Гайденка у вітчизняній баянній культурі: «творчість Гайденка уособлює < ..> 
парадигму невичерпного потенціалу традиційності, сфокусованої в історично стабільному тандемі жанр - народний інструмент. Відтак, творчість композитора є зразком музики перехідного етапу, з властивими для неї фантомами канонічного, відсвіженого відблисками нестандартних явищ сучасної мови, характерні акценти якої аж ніяк не руйнують народно-жанрової генези виражального комплексу» $[6,63]$.

\section{СПИСОК ЛІТЕРАТУРИ}

1. Арановский М. Музыкальный текст: структура и свойства. Москва: Композитор, 1998. 344 с.

2. Барток Б. О влиянии крестьянской музыки на музыку нашого времени. Бела Барток: сб. статей / [сост. Е. И. Чигарева]. Москва: Музыка, 1977. C. $245-249$.

3. Большакова Т. Концертні твори для баяна А. Гайденка: посібник для студентів та викладачів вищих музичних навчальних закладів. Харків: ХДАК, 2007. $118 \mathrm{c}$.

4. Іваницький А. Українська народна музична творчість: навч. посібник / [під ред. М. Поплавського]. 2-ге вид., доп. Київ: Музична Україна, 1999. 222 с.

5. Коновалова I. Феноменологія музичної обробки (на матеріалі хорових творів українських композиторів XIX-XX ст.): автореф. дис. ... канд. мистецтвознавства: 17.00.01 / Харківська держ. академія культури. Харків, 2007. 19 с.

6. Кужелев Д. Баянна творчість українських композиторів: навч. посібник. Львів: Сполом, 2011. 206 с.

7. Протопопова О. Поставангардний діалог «композитор - фольклор»: до постановки проблеми. Київське музикознавство. Культурологія та мистецтвознавство: зб. ст. Київ: НМАУ м.. П. І. Чайковського, КІМ м. Р. М. Глієра, 2012 . Вип. 41. С. 147-156.

8. Семешко А. Анатолий Гайденко: Портреты современных украинских композиторов-баянистов (в форме диалогов). Харьков: Майдан, 2010. 82 с.

\section{REFERENCES}

1. Aranovskiy, M. (1998). Music text: structure and properties. Moskoy: Kompozitor [in Russian].

2. Bartok, B. (1977). On the influence of peasant music on the music of our time. Chigareva E. I. Bella Bartok. Moskoy: Muzika [in Russian].

3. Bolshakova, T. (2007). Concert works for the accordion by A. Gaidenko. Kharkiv: KhDAK [in Ukrainian].

4. Ivanyczkyj, A. (1999). Ukrainian folk musical creativity. Poplavskiy M. (Eds). Kyiv: Muzychna Ukrayina [in Ukrainian].

5. Konovalova, I. (2007). Phenomenology of musical processing (on the material of choral works of Ukrainian composers of the XIX-XX centuries). Extended abstract of candidate's thesis. Kharkiv: KhNUM im. I. P. Kotliarevskogo [in Ukrainian]. 
6. Kuzhelev, D. (2011). Bayan creativity of Ukrainian composers. Lviv: SPOLOM [in Ukrainian].

7. Protopopova, O. (2012). The post-dialogue dialogue «composer - folklore»: to the problem statement. Kyiv musicology. Culturology and Art Studies, 41. Kyiv: NMAU im. P. I. Chajkovskogo, KIM im. R. M. Gliera [in Ukrainian].

8. Semeshko, A. (2010). Anatoly Gaidenko: Portraits of modern Ukrainian composers-bayanists (in the form of dialogues). Kharkov: Maydan [in Ukrainian].

Стаття надійшла до редакції 14.06.2017

УДК 784.087.68«20»(477)

\author{
Оксана Іванівна Дондик \\ https://orcid.org/0000-0002-9181-5242, \\ заслужена артистка України, \\ старший викладач \\ кафедри академічного хорового мистецтва \\ Київського національного університету культури і мистецтв \\ dondikoi@ukr.net

\section{НОВІТНІ ЖАНРОВО-СТИЛЬОВІ ТЕНДЕНЦІЇ У КОНЦЕРТНІЙ ДІЯЛЬНОСТІ АКАДЕМІЧНОГО КАМЕРНОГО ХОРУ «ХРЕЩАТИК»} \\ (на прикладі аналізу сценічного проекту \\ «Класика жартома: Choir Smiles»)
}

\begin{abstract}
Мета дослідження: проаналізувати прояви новітніх жсанрово-стильових тенденцій, котрі простежуються у сучасній концертно-сценічній практиці Академічного камерного хору «Хрещатик» (на прикладі аналізу сценічного проекту «Класика жартома: Choir Smiles»). Методологія дослідження грунтується на застосуванні універсальних наукових методів: індукції, дедукції, аналізу, синтезу, структурного та компаративного аналізу, систематизації, узагальнення. Використання вказаних методів дає змогу виявити і детально проаналізувати концертно-сценічні та образно-драматургічні параметри, покладені в основу творчих пошуків y процесі роботи над мистецьким проектом «Класика жартома: Choir Smiles». У цьому контексті особливого значення набуває аналіз оригінальних новаційних алгоритмів, творчо втілених режисером-постановником та керівництвом хору, сутність яких актуалізується на перетині різних мистецьких площин та жсанрово-стильових і хронотопічних ареалів. Наукова новизна полягає у збагаченні сучасного музикознавства новими аналітичними розробками та спостереженнями щодо функціонування новітніх жанрово-стильових тенденцій у сучасній вітчизняній камерно-
\end{abstract}

(C) Дондик О. I., 2017 